University of Nebraska - Lincoln

DigitalCommons@University of Nebraska - Lincoln

2008

\title{
Movements of Wintering Dunlin Calidris alpina and Changing Habitat Availability in an Agricultural Wetland Landscape
}

Oriane W. Taft

U.S. Geological Survey, oriane_taft@msn.com

Peter M. Sanzenbacher

$A B R$, Inc.

Susan M. Haig

U.S. Geological Survey, Susan_Haig@usgs.gov

Follow this and additional works at: https://digitalcommons.unl.edu/usgsstaffpub

Taft, Oriane W.; Sanzenbacher, Peter M.; and Haig, Susan M., "Movements of Wintering Dunlin Calidris alpina and Changing Habitat Availability in an Agricultural Wetland Landscape" (2008). USGS Staff -Published Research. 678.

https://digitalcommons.unl.edu/usgsstaffpub/678

This Article is brought to you for free and open access by the US Geological Survey at DigitalCommons@University of Nebraska - Lincoln. It has been accepted for inclusion in USGS Staff -- Published Research by an authorized administrator of DigitalCommons@University of Nebraska - Lincoln. 


\title{
Movements of wintering Dunlin Calidris alpina and changing habitat availability in an agricultural wetland landscape
}

\author{
ORIANE W. TAFT, ${ }^{1,2 *}$ PETER M. SANZENBACHER ${ }^{1,2} \dagger$ \& SUSAN M. HAIG ${ }^{1}$ \\ ${ }^{1}$ USGS Forest and Rangeland Ecosystem Science Center, 3200 SW Jefferson Way, Corvallis, OR 97331, USA \\ ${ }^{2}$ Department of Fisheries and Wildlife, Oregon State University, Corvallis, OR 97331, USA
}

Few studies have assessed how the dynamics of wetland bird movements relate to changing resource availability, particularly at more than one spatial scale. Within western Oregon's Williamette Valley, we examined winter resident Dunlin Calidris alpina movements in relation to a decrease in availability of preferred shorebird foraging habitat from early to late winter of 1999-2000. By tracking movements of 15 (early winter) and 12 (late winter) radiomarked individuals, we calculated home ranges and characterized presence/absence of a preference for shorebird foraging habitat during each winter period. Between periods, we compared: (1) percentage of shorebird habitat in home ranges to its availability in the landscape (regional preference), (2) percentage of radio locations in shorebird habitat to its availability within home ranges (local preference) and (3) relative use of roost sites. Concurrent with a $75 \%$ decrease in available shorebird habitat from early to late winter, average home range sizes increased by a factor of 3.8. At a regional scale, home ranges in early winter included a significantly greater percentage of shorebird foraging habitat than was available in the wider landscape. However, by late winter, the percent of shorebird habitat in home ranges did not match availability in the landscape. At the local scale, for both winter periods Dunlin were located in shorebird foraging habitat more often than expected given availability of habitat within home ranges [Correction added after online publication 23 May 2008: sentence amended]. An increase in the number of roosts used from early to late winter implies possible reliance on additional sites in late winter for foraging opportunities. Results suggest that wet, unvegetated habitat is sought by Dunlin throughout winter, but individuals could not select home ranges in late winter that fully compensated for seasonal loss of habitat.

Keywords: foraging, habitat preference, habitat use, home range, roosts, shorebirds.

Wetland habitats are inherently changeable in space and time (Skagen \& Knopf 1994, Robinson \& Warnock 1997), and the waterbirds that depend on them during a given period of time face a constant challenge of finding the minimum collective resources to survive (Connors et al. 1981, Kushlan 1986, Arengo \& Baldassarre 1999, van Gils et al. 2006). Shorebirds (suborder Charadrii) are a waterbird group that is notorious for coping with these changing wetland environments on a daily cycle often associated with

*Corresponding author.

Email: oriane_taft@msn.com

tPresent address: ABR, Inc. - Environmental Research and Services, PO Box 249, Forest Grove, OR 97116, USA. tides (Pitelka 1977, Myers 1986, Ruiz et al. 1987, Dias et al. 2006, Rosa et al. 2006), and for opportunistically finding newly available habitat in any wetland system at local (in metres) and regional (in kilometres) scales (Connors et al. 1981, Skagen \& Knopf 1993, 1994, Warnock et al. 1995, Warnock \& Takekawa 1996, Roshier et al. 2001). In coastal habitats where the availability of intertidal foods fluctuates predictably in accordance with the tide, a number of researchers have examined strategies used by shorebirds to track and obtain enough daily resources to survive (Evans 1976, Connors et al. 1981, Butler et al. 2002, Luis et al. 2002, Smart \& Gill 2003, Shepherd \& Lank 2004, van Gils et al. 2004, 2005, 2006, Evans Ogden et al. 2006). However, less is known regarding how 
shorebirds alter their daily movements and use of habitat to endure in landscapes where the collective availability of wetland food resources may dramatically change over the course of a season. In non-tidal wetland systems in particular, food resources are more ephemeral relative to those of coastal areas (Skagen \& Knopf 1993, Reed et al. 1997), and regional patterns of precipitation, evaporation and vegetation growth can result in wetland mosaics that are highly dynamic over a given season. In such landscapes, it seems likely that shorebirds would correspondingly adjust their use of habitat throughout a seasonal period of residency in order to meet minimum energy requirements. Documenting such a response would contribute not only to our understanding of how organisms interact with entire wetland landscapes, a relatively new question in wetland ecology, but may also enable predicting species' responses to more pervasive wetland habitat loss at larger spatial and temporal scales.

The Willamette Valley of western Oregon, USA (hereafter 'Valley'), is a dynamic agricultural wetland landscape that is winter residence to 40000 or more shorebirds, most of which are Dunlin Calidris alpina (Sanzenbacher \& Haig 2002a, 2002b, Taft \& Haig 2003). Valley Dunlin exhibit a high degree of fidelity to the region during the winter, which has been established by telemetry data showing long durations of continual observation and minimal time elapsed between detections of radiomarked birds (Sanzenbacher \& Haig 2002a). Moreover, movement of individuals among multiple sites throughout the winter period (Sanzenbacher \& Haig 2002a) and fairly low abundances of invertebrate food resources in most Valley wetlands (Taft \& Haig 2005) suggest that Dunlin need to visit numerous foraging sites in order to meet their energetic needs. Nonetheless, the fidelity of wintering Dunlin to the Valley implies that wetlands in this region collectively provide enough resources for birds to remain in this landscape throughout the winter.

Valley wetlands that provide foraging habitat to shorebirds are of two general types: (1) agricultural wetlands ('palustrine emergent-farmed wetlands' of Cowardin et al. 1979) - changeable habitats with saturated or ponded soils on unvegetated $(\leq 50 \%$ cover) and newly planted or winter-fallow cropland; and (2) managed wetland impoundments and sewage ponds - more stable wetland resource offering permanent standing water throughout the winter. Agricultural wetlands account for most wetland habitat in the Valley and are used primarily for foraging. The fewer, more permanent waterbodies may serve as foraging sites towards spring as water evaporates and drawdowns occur, but are primarily used as roost sites throughout winter (Sanzenbacher 2002). Agricultural wetland crops primarily include grasses grown to produce marketable seed (Annual Ryegrass Lolium multiflorum, Perennial Ryegrass L. perenne and Tall Fescue Festuca arundinacea; Hulse et al. 2002). As these are all winter-grown and spring/summer-harvested crops, grass field substrates are most exposed from autumn planting through early winter, and least exposed towards the spring/ summer harvest. Thus, from early to late winter, as crop plants grow, rainfall subsides and evapotranspiration increases, shorebirds experience a dramatic and widespread decline in the regional availability of foraging habitat (Taft et al. 2004).

This dramatic contraction of wetland habitat over the winter led us to consider how Valley-wintering Dunlin acquire enough resources to remain in the region. During one winter of average rainfall, we studied changes in habitat use, movements and home range sizes of radiomarked Dunlin in relation to changes in habitat availability across the Valley landscape. Our objectives were to quantify and assess for an early winter (December to early February) and late winter (mid February to early April) period: (1) home range size and amount of preferred shorebird foraging habitat encompassed within home ranges relative to availability of habitat across the landscape; (2) whether birds selected preferred shorebird habitat disproportionate to its availability at a regional (home ranges) and local (foraging sites within home ranges) spatial scale; and (3) relative use of roost sites in the Valley.

\section{METHODS}

\section{Study area}

The Willamette Valley (approximate midpoint $44^{\circ} 40^{\prime} \mathrm{N}, 123^{\circ} 0^{\prime} \mathrm{W}$ ) encompasses $9100 \mathrm{~km}^{2}$ of lowland plains (Clark et al. 1991, Benner \& Sedell 1997) within Oregon's Willamette Basin, a $29000-\mathrm{km}^{2}$ watershed between Oregon's Cascade and Coast ranges (Fig. 1; Hulse et al. 2002). The prominent hydrological feature of the Valley is the Willamette River and its 13 major tributaries (Benner \& Sedell 1997). Agriculture and urban development have extensively altered the native wetlands (primarily wetland prairie) and landforms of the Valley (Hulse et al. 2002, Taft \& Haig 2003). Today, remaining Valley wetlands include small urban remnant 


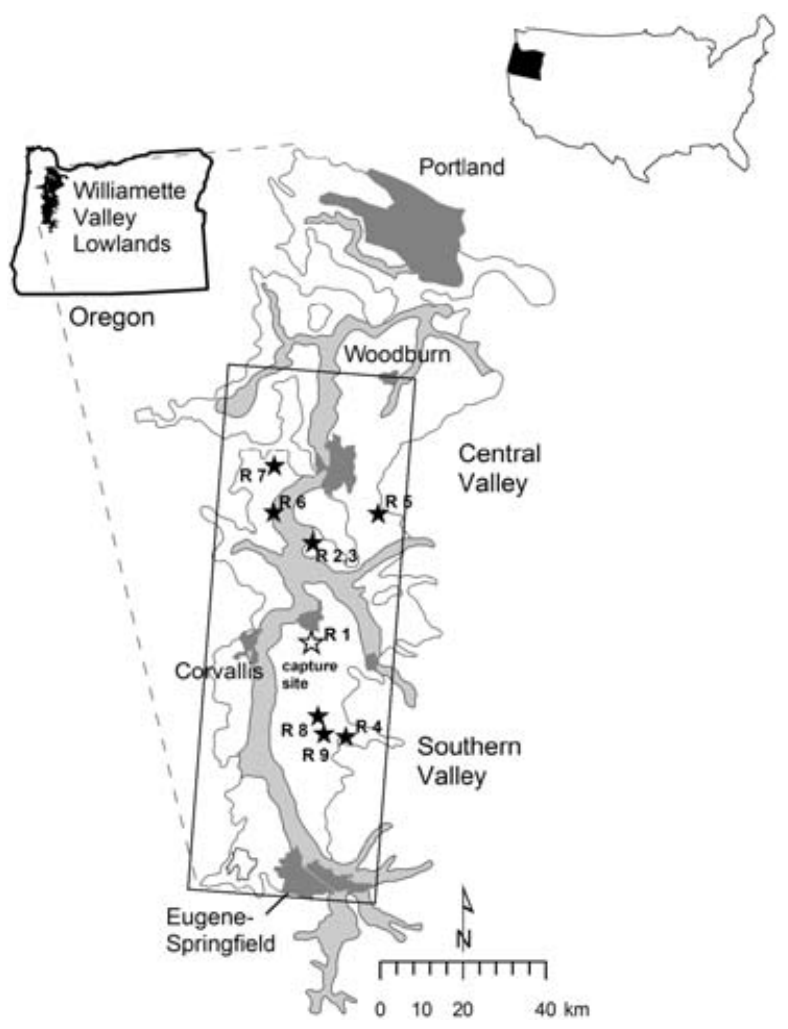

Figure 1. The Willamette Valley lowlands of western Oregon, USA, including locations of the capture site and roosts used by radiomarked Dunlin during the winter of 1999-2000. The box delineates the area regularly covered in telemetry searches. The area in grey depicts the Willamette River floodplain, area in white depicts Valley alluvial terraces and areas in dark grey are urban. Roost sites (stars) enumerated as R1, R2, etc.

wetlands, a few private duck hunting reserves, four larger state and federally protected wildlife refuges, and hundreds of scattered privately owned agricultural wetlands. The climate of the Valley is cool Mediterranean, with an average annual rainfall of $100-125 \mathrm{~cm}$, $75 \%$ of it falling between October and March (Jackson \& Kimerling 1993); average temperatures range from $1{ }^{\circ} \mathrm{C}$ in January to $30^{\circ} \mathrm{C}$ in July (data from Oregon Climate Service: www.ocs.oregonstate.edu/index.html). We conducted our study from December to April of 1999-2000, an average winter for precipitation $(91 \mathrm{~cm}$ from October to March; Oregon Climate Service). See Sanzenbacher and Haig (2002a, 2002b) and Taft and Haig $(2005,2006)$ for further details on characteristics of the study area.

\section{Land cover data}

Previous studies indicate shorebirds prefer moist to flooded foraging substrates that are sparsely vegetated (e.g. Rundle \& Fredrickson 1981, Fredrickson \& Reid 1986, Colwell \& Oring 1988). Taft and Haig (2006) similarly observed an association in the Valley between foraging shorebird use and shallow, wet (flooded or saturated), exposed ( $\leq 50 \%$ vegetation cover) habitat, particularly for Dunlin. We therefore used a combination of remotely sensed imagery and data acquired in the field to map the temporal variation in the availability of this predicted preferred winter foraging habitat for shorebirds (hereafter 'shorebird habitat') in the Valley (Taft et al. 2004). We used radar (RADARSAT International, www.rsi.ca) imagery at 8-m resolution taken on 10 December 1999 and 15 March 2000 to produce two layers in a geographical information system (GIS; Erdas Imagine 8.6, Erdas, Inc., Atlanta, GA, USA) depicting the distribution of shorebird habitat in early winter and late winter, respectively. Shallow water within impounded seminatural wetlands on refuges, rice fields and sewage ponds was also mapped as shorebird habitat. 'User's Accuracy' (also termed 'commission error' or the proportion of sites assigned to a class that are truly of that class) for shorebird habitat ranged from $72 \%$ (135 of 187 ground reference sites correctly classified) to $80 \%$ (82 of 103 sites) between winter periods. Remaining non-urban, non-perennial land cover was mapped as one of three habitat types classified by wetness and vegetative cover: (1) wet, vegetated (> 50\% vegetation cover); (2) dry, exposed ( $\leq 50 \%$ vegetation cover); and (3) dry, vegetated (>50\% vegetation cover) habitat. Map accuracies for these three land cover classes were extremely low (varying from 24 to 50\%), however, precluding inferences regarding the relative use of each of these lesspreferred habitats by Dunlin in each winter period. See Taft et al. (2004) for further details on creation of land cover maps from radar data.

\section{Capturing and marking Dunlin}

We captured Dunlin at a single site in the central part of the Valley $\left(44^{\circ} 34^{\prime} \mathrm{N}, 123^{\circ} 06^{\prime} \mathrm{W}\right.$; Fig. 1) during early December 1999 (early winter) and mid February 2000 (late winter). The capture site was a fallow corn field with pastured sheep and a 2.5-ha pond. Single counts as high as 20000 individuals identified the site as a major roosting (at the pond) and feeding area for Dunlin. Birds were captured at night with noose-mats placed in foraging areas (Drake et al. 2003). Captured individuals were fitted with 1.6-g radio-transmitters with individual frequencies and an estimated battery life of 8 weeks 
(model BD-2, Holohil Systems Ltd, Carp, Ontario, Canada). Transmitters were attached using a legloop harness (Sanzenbacher et al. 2000). The weight of the combined markers and harness package ranged from 1.86 to $1.96 \mathrm{~g}$ and averaged $3.7 \%$ of the body mass of captured Dunlin.

\section{Radiotracking}

We tracked movements of individuals in the Valley for the majority of transmitter life: from early December through early February for early winter radiomarked birds, and from mid February to early April (average spring departure date was $22 \mathrm{March}$ ) for late winter birds. In this inland, non-tidal landscape, Dunlin typically forage in dispersed agriculture fields during much of the day and an unknown proportion of the night, with numbers peaking at roost sites (typically impounded water) during afternoon and crepuscular hours (Sanzenbacher \& Haig 2002a). We used ground and aerial surveys to search for birds primarily during the day (08:00-16:00 h), but also made an effort to search for birds at night and to track movements from diurnal to nocturnal sites. The approximate percentages of locations collected during nocturnal hours ( $>45 \mathrm{~min}$ after sunset to $<45 \mathrm{~min}$ prior to sunrise) were $16 \%$ for early winter and 13\% for late winter. Searches included all known high-use sites and wetland concentrations in the Valley, as well as intervening areas, and these sites were searched at least bi-weekly. We made a concentrated effort to search previously unexplored potential habitat in the Valley on a weekly basis (Fig. 1).

Daily ground telemetry efforts entailed two observers independently searching for radiomarked birds using trucks outfitted with dual Yagi, fourelement, null-peak antenna systems. Mean ( \pm sd) range of transmitter detection from the ground was $1.4 \pm 0.3 \mathrm{~km}$ (range 0.9-1.8 km; Sanzenbacher \& Haig 2002a). To determine the location of radiomarked birds, we recorded at two or more positions: bird azimuth, truck orientation and exact location of the telemetry vehicle using a geographical positioning system (GPS; Trimble Navigation, Sunnyvale, CA, USA). We collected all location data for a given frequency within a 10-min period to reduce the probability that a focal bird had moved. As weather permitted, we also conducted weekly to biweekly aerial flights to locate radiomarked birds and identify additional areas of potential shorebird habitat to search by ground. All telemetry data were entered into the program LOAS (Ecological Software Solutions, Sacramento, CA, USA) to estimate locations of individuals. As determined by concurrent assessments of the accuracy of estimated locations, mean $( \pm \mathrm{sd})$ estimated radio location error was $33 \pm 9$ m (Sanzenbacher \& Haig 2002a).

\section{Data summary and analyses}

\section{Calculating home ranges}

Prior to calculating home ranges, we randomly selected no more than three locations for an individual in a single day, and only used locations separated by more than $30 \mathrm{~min}$ to minimize non-independence among observations. As the 30-min interval was a sufficient amount of time for a Dunlin to complete the longest direct flight observed in the region, we also felt it was a good compromise between inappropriate subsampling and loss of biologically relevant information (De Solla et al. 1999, Otis \& White 1999). In most cases, time between successive locations was much greater (e.g. mean $=48 \mathrm{~h}$, with $96.6 \%$ of observations separated by more than $1 \mathrm{~h}$, and $30.6 \%$ of observations greater than $48 \mathrm{~h}$ apart).

We considered a number of approaches to calculating home ranges focusing primarily on minimum convex polygons (MCPs) and fixed kernels (White \& Garrott 1990, Hooge \& Eichenlaub 1997, Seaman et al. 1998). We found that in some cases fixed kernels overestimated home range size and were sensitive to both our small sample sizes and the distribution of bird locations (i.e. widespread and often clustered). In contrast, MCPs were generally smaller but included areas encompassed by bird locations and of potential interest that fixed kernels excluded. Ultimately, we determined that MCPs were most appropriate based on both the objectives of the study and comparisons with fixed kernel results.

We calculated 95\% MCP home ranges using ArcView GIS software (ESRI, Inc., Redlands, CA, USA) and the Animal Movement extension (Hooge \& Eichenlaub 1997). Mean ( \pm se) number of locations per individual was $20 \pm 1.6$ in early winter $(n=23)$ and $17 \pm 1.8$ in late winter $(n=18)$. Previous work has shown a negative bias in MCP area with low numbers of locations (White \& Garrott 1990, Mazur et al. 1998). In contrast, our data indicated a nonsignificant but slight positive trend in area bias with low location sample sizes. Thus, to limit area biases due to small number of locations, we only included birds with at least 15 locations in analyses. These restrictions resulted in sample sizes of 15 individuals 
for the early winter analysis and 12 individuals for the late winter analysis. For these final samples, the mean number of locations per individual was 24 (range 16-34) in early winter and 22 (range 15-30) in late winter.

\section{Regional preference for shorebird habitat}

Using Erdas Imagine 8.6 GIS software, with our land-cover data we were able to quantify area (ha) of shorebird habitat within the Valley landscape and within each home range during early winter and late winter. For each individual in each period, we then divided percentage of home ranges comprising shorebird habitat by percent cover of shorebird habitat in the Valley landscape to generate a regional 'preference ratio' (e.g. Lovvorn \& Kirkpatrick 1982, Warnock \& Takekawa 1995), depicting degree of preference for home ranges with high coverage of shorebird habitat. A preference ratio greater than 1 indicates that a bird encompassed disproportionately more shorebird habitat in its home range than was widely available in the landscape. Within winter periods, we examined whether birds consistently exhibited a regional preference for shorebird habitat using a one-sample $t$-test for the mean preference ratio > 1 (SAS Institute Inc. 1999).

\section{Local preference for shorebird habitat}

To ensure that our analysis of local preference for shorebird habitat evaluated a preference for habitats used primarily for foraging (as opposed to habitat used for other purposes), we excluded bird locations at sites that appeared to be used strictly for roosting at the time of observation (those with only impounded deep water and with none to minimal foraging habitat) or at which birds had been observed solely in flight. Because Sanzenbacher and Haig (2002a) previously estimated an average error in transmitter location of $33 \mathrm{~m}$, for each bird location we tabulated in ArcView 3.2 the amount (ha) of shorebird (wet, $\leq 50 \%$ vegetation cover) and less-preferred (all other land cover classes combined) habitat within a 33-m-radius circular buffer centered on the location, and considered the location as having been in that habitat accounting for the majority (> 50\% of area) of the buffer. For each individual in each winter period, we then divided the percent of bird locations in shorebird habitat by the percent cover of shorebird habitat in home ranges to generate a local preference ratio depicting degree of preference for shorebird habitat sites within home ranges. A preference ratio greater than 1 suggests use of shorebird habitat in greater proportion than its availability within home ranges. Within periods, we examined whether birds consistently exhibited a local preference for shorebird habitat using a one-sample $t$-test for the mean preference ratio > 1 (SAS Institute Inc. 1999).

\section{Roost sites}

We most simply defined roost sites as locations where we observed concentrations of Dunlin. Within the Valley, these were typically impounded deepwater habitats with exposed edges or islands on which birds could rest. Due to managed drawdowns or evaporative water loss at these sites, on occasion these roosts could also provide foraging habitat. We evaluated differences in the use of roost sites each season by (1) assessing which sites were used, and (2) quantifying the percentage of bird locations in MCPs that were located at known roosts. We evaluated whether proportional use of roost sites were different between early and late winter using a two-sample $t$-test for unequal variances (SAS Institute Inc. 1999).

\section{RESULTS}

Growth of crop vegetation, declining monthly rainfall and evaporative water loss towards spring each contributed to a dramatic decrease in the availability of shorebird habitat between early and late winter (also see Taft et al. 2004). Whereas shorebird habitat could be found on $16 \%$ of the landscape in early winter, only $4 \%$ of the Valley provided this habitat by late winter (Table 1), representing a $75 \%$ reduction in shorebird habitat between winter periods. Average amount of shorebird habitat encompassed by home ranges correspondingly declined from 30 to $18 \mathrm{~km}^{2}$ (Table 1), a $40 \%$ reduction in amount of habitat within home ranges. Home range size significantly increased from $147 \pm 28 \mathrm{~km}^{2}$ in early winter to $565 \pm 100 \mathrm{~km}^{2}$ by late winter $\left(F_{237}=11.80, P<0.01\right.$; see also Sanzenbacher \& Haig 2002a).

Patterns of preference for shorebird habitat at regional and local scales varied between winter periods. In early winter, percent of MCP area comprising shorebird habitat was on average $25 \%$ among radiomarked Dunlin (Table 1). Given the 16\% cover for shorebird habitat across the Valley landscape in early winter, regional preference ratios (mean $=1.51$ among individuals) were consistently greater than 1 $\left(t_{14}=2.95, P=0.005\right.$; Table 1$)$. In addition, within home ranges, percent of total radio locations in 
Table 1. Amount of shorebird habitat within the Valley (an absolute value), within home ranges (mean \pm sd), and identified as the predominant habitat type of bird locations within home ranges (mean $\pm \mathrm{sd}$ ), with regional and local preference ratios (mean \pm sd) derived from these measures for 15 (early winter) and 12 (late winter) radiomarked Dunlin studied during the winter of 1999-2000 in the Willamette Valley, Oregon, USA.

\begin{tabular}{|c|c|c|c|c|c|c|c|c|}
\hline \multirow[b]{3}{*}{ Winter period } & \multirow[b]{3}{*}{ Home range size $\left(\mathrm{km}^{2}\right)$} & \multicolumn{5}{|c|}{ Shorebird habitat } & & \\
\hline & & \multicolumn{2}{|c|}{ Valley } & \multicolumn{2}{|c|}{ Home range } & \multirow{2}{*}{$\frac{\text { Bird locations in home range }}{\%}$} & \multicolumn{2}{|c|}{ Preference ratio } \\
\hline & & $\mathrm{km}^{2}$ & $\%$ & $\mathrm{~km}^{2}$ & $\%$ & & Regional* $^{*}$ & Local $^{*}$ \\
\hline Early winter & $147 \pm 28$ & 814 & 16 & $30 \pm 19$ & $25 \pm 11$ & $50 \pm 19$ & $1.51 \pm 0.66$ & $2.29 \pm 0.93$ \\
\hline Late winter & $565 \pm 100$ & 200 & 4 & $18 \pm 12$ & $3 \pm 1$ & $24 \pm 22$ & $0.76 \pm 0.21$ & $8.12 \pm 7.26$ \\
\hline
\end{tabular}

${ }^{*}$ Significant relationships $(P<0.05)$ are in bold type.

shorebird habitat averaged 50\% among individuals (Table 1), and given the percent area of MCPs providing shorebird habitat (mean $=25 \%$ ), local preference ratios (mean $=2.29$ among individuals) were also significantly greater than $1\left(t_{14}=5.38\right.$, $P<0.0001$; Table 1 ). On average, $50 \%$ of radio locations were located in less-preferred habitats.

In contrast, during late winter, percent of MCP area comprising shorebird habitat was on average only 3\% among individuals (Table 1). With shorebird habitat availability across the Valley landscape at only $4 \%$ land cover, regional preference ratios (mean $=0.76$ among individuals) were no different than $1\left(t_{11}=-3.91, P=0.99\right.$; Table 1$)$. However, within home ranges, percent of total radio locations in shorebird habitat averaged $24 \%$ among individuals (Table 1), which when compared with the percent area of MCPs providing shorebird habitat (mean = $3 \%$ resulted in local preference ratios significantly greater than 1 (mean $=8.12$ among individuals; $t_{11}=3.40, P=0.003$; Table 1). Percent of radio locations in less-preferred habitats increased on average from 50 to $76 \%$ in late winter.

Between early and late winter, mean ( \pm sd) percent of bird locations in MCPs at known roost sites increased significantly $(t=3.61, P=0.003, \mathrm{df}=14.24$ for unequal variance) from $34 \pm 8 \%$ to $54 \pm 18 \%$. In addition, the number of roosts regularly used by individuals increased from four sites in early winter to nine sites in late winter. The four roost sites used in early winter were also used in late winter and were centrally located within the Valley (sites Rl-R4; Fig. 1). However, an additional five roost sites were visited by radiomarked birds in late winter (site R5R9), and three of these were located further north than the original four roosts used in early winter (see Fig. 1).

\section{DIsCussion}

Patterns of Dunlin habitat use and movements observed in the Valley were consistent with other examples of shorebird species' reliance on multiple sites of a variety of habitat types within a given wetland landscape (e.g. Symonds et al. 1984, Warnock \& Takekawa 1996, Plissner et al. 2000, Drake et al. 2001, Butler et al. 2002, Smart \& Gill 2003, Evans Ogden et al. 2006). Our study, however, goes beyond documenting this reliance to examine how shorebirds may adjust their movements and habitat use within a landscape to accommodate temporal changes in the abundance and spatial distribution of such sites (Table 1). A few studies have documented changes in species' habitat use or movements within a region to take advantage of a short-term increase in the availability of a particular resource. Towards the end of the breeding period in Alaska, Connors et al. (1979) observed that various shorebird species expanded their foraging activities from the coastal tundra to include and eventually switch to nearby littoral resources as the melting of sea ice increased access to the marine shoreline. Similarly, in the southern Laguna Madre of Texas, Drake et al. (2001) documented an increase in home ranges of Piping Plovers Charadrius melodus as birds temporarily increased their movements from barrier island tidal flats to take advantage of adjacent mainland mudflat habitats exposed by periodic seiche activity (standing waves in an enclosed or partially enclosed body of water). We are unaware of any studies of wetland birds, however, that have quantified a potential compensation in habitat use and movements within a landscape in response to a natural contraction in the availability of habitat within a season. 
Our study suggests that Valley Dunlin certainly responded to and potentially tried to compensate for a decline in the availability of foraging habitat over the course of the winter. At a regional scale, in early winter, Dunlin home ranges encompassed proportionately more shorebird foraging habitat than was generally available across the landscape (regional preference ratios significantly $>1$ ), and within these home ranges, birds used sites with shorebird habitat more than expected given availability of habitat. The preference for wet, unvegetated ( $\leq 50 \%$ cover) foraging habitat at regional (within the Valley landscape) and local (within home ranges) scales in early winter suggests that shorebird habitat is genuinely important to Dunlin wintering in the Valley. The nearly fourfold increase in home range size through winter, coincident with a $75 \%$ reduction in the availability of shorebird habitat in the Valley, suggests that Dunlin attempted to compensate for the seasonal loss of this preferred habitat by increasing their movements to use a collection of sites spaced further apart. This increase appeared to be effective to some degree, as the amount of shorebird habitat within home ranges declined by $40 \%$ instead of corresponding to the $75 \%$ reduction observed between periods in the amount of habitat available across the greater Valley. However, habitat was sparse by late winter such that it may not have been possible to select home ranges with a greater proportion of shorebird habitat than was available across the Valley as a whole. Many birds came short of even matching (preference ratios close to 1) the low availability of habitat in the landscape with an expansion in their home range, as indicated by a late winter mean regional preference ratio substantially less than 1 . These data, along with a continued local preference for shorebird habitat within home ranges in late winter, beg the question of whether this compensation was adequate to meet the energetic needs of Dunlin towards the end of their winter residency in the Valley. During a concurrent study conducted in the Valley during the same winter, Taft and Haig (2006) observed an increase in Dunlin densities at agricultural wetland sites towards late winter, supporting the notion that habitat may have become limited by the end of winter. Moreover, in the present study, the proportion of locations in less-preferred habitats (i.e. in one of the other three mapped land-cover types) increased from 50 to $76 \%$ by late winter (Table 1). This further implies that preferred foraging habitat and/or food resources within preferred sites became limiting towards late winter, forcing birds to exploit less- preferred habitats. To answer fully whether a compensation in habitat use was enough to maintain birds would require assessing whether Valley Dunlin fat reserves are depleted beyond the minimum levels necessary to survive the winter and prepare for spring migration (e.g. Pienkowski et al. 1979, Dick \& Pienkowski 1979, Lyons \& Haig 1995).

A greater percentage of locations within home ranges were at roost sites in late winter than early winter, and a number of roost sites were only used in late winter as foraging habitat became more limited. There are several plausible explanations as to why Dunlin used roost sites to a greater extent in late winter. A simple explanation would be that Dunlin increased the time spent roosting, perhaps related to pre-migration social interactions associated with zugenruhe (migratory unrest). Increased late winter use of roosts could also be related to their proximity to foraging locations. In the Tagus Estuary of Portugal, Dias et al. (2006) found that wintering Dunlin tended to forage in tidal flats that were near $(<5 \mathrm{~km})$ suitable roost sites, and that foraging sites may be underused if they are too far from roosts. Following a similar but converse scenario, it is possible that the broader foraging movements of individuals (increased home range size) in late winter brought birds closer to more distant roost sites in the Valley, increasing the odds that these roosts would be used. Another explanation could be that roosts used early in the season may have changed in suitability in some way by late winter (e.g. growth of vegetation, predation pressure) such that the use of additional roosts became necessary. Finally, we observed that a number of roost sites that had deep water in early winter had begun to provide exposed substrates by late winter, and thus the value of these roosts as foraging habitat could explain their increased use as habitat on agricultural wetlands decreased. This notion may be supported by other research indicating that shorebirds are always maximizing feeding opportunities to meet their energetic needs (Rosa et al. 2006, van Gils et al. 2006). Rosa et al. (2006) observed a preference by some wintering shorebird species (including Dunlin) in Portugal for roost sites that also provided some foraging habitat (intertidal mudflats at neap or intermediate tides) over those that did not (saltpans) during high tide when the availability of habitat was temporarily limited. As these explanations are not mutually exclusive, it is possible that all four contributed to a change in the use of roost sites in the Valley towards late winter.

Wetlands have been lost globally at an alarming rate (Frayer et al. 1983, Dahl 1990, Mitsch 1994), 
and agricultural and urban development continues to threaten the quantity and quality of wetlands today. Inferences regarding the within-season change in habitat use demonstrated by Valley Dunlin are no doubt limited by the observational nature of our study. We were unable to assess the relative influence of other potential causal factors, such as changes in predation pressure or weather, on the expansion of home ranges exhibited by Dunlin. Whether shorebird habitat truly became limiting to shorebirds by late winter, and whether home range expansions to potentially compensate for the contraction of habitat were adequate to meet the energetic needs of birds are also unknown. However, any knowledge of strategies potentially used by shorebirds to respond to natural habitat fluctuations provides valuable information towards predicting the potential impact on birds of more permanent loss of habitat. We argue that studying these dynamics, although labourintensive and difficult, is a worthwhile endeavour towards developing conservation strategies for wetland landscapes.

We are grateful to J. Dhundale, M. Henschen, W. Jensen, H. Packard and M. Taft for countless hours in the field trapping and tracking birds, and for their help in collecting ground reference data for land-cover mapping efforts. We thank pilot W. Moreland for assistance with aerial surveys, J. Beall, K. Bierly, R. Goggans, J. Morlan, M. Naughton, C. Schuler, S. Smith and B. Taylor for their advice, and technical and logistical assistance, and G. Lienkaemper, C. Kiilsgaard, D. Oetter and R. Kennedy for GIS support. Numerous landowners provided access to properties and relevant information on natural history of the region. Support for the project was generously provided by the Oregon Watershed Enhancement Board, USGS Forest and Rangeland Ecosystem Science Center, US Fish and Wildlife Service, Oregon Department of Fish and Wildlife, and Bureau of Land Management.

\section{REFERENCES}

Arengo, F. \& Baldassarre, G.A. 1999. Resource variability and conservation of American Flamingos in coastal wetlands of Yucatan, Mexico. J. Wildl. Manage. 63: 1201-1212.

Benner, P.A. \& Sedell, J.R. 1997. Upper Willamette River landscape: a historic perspective. In Laenen, A. \& Dunette, D.A. (eds) River Quality: Dynamics and Restoration: 23-47. Boca Raton, FL: Lewis Publishers.

Butler, R.W., Shepherd, P.C.F. \& Lemon, M.J.F. 2002. Site fidelity and local movements of migrating Western Sandpipers on the Fraser River Estuary. Wilson Bull. 114: 485-490.

Clark, S.E., White, D. \& Schaedel, A.L. 1991. Oregon, USA, ecological regions and subregions for water quality management. Environ. Manage. 15: 847-856.
Colwell, M.A. \& Oring, L.W. 1988. Habitat use by breeding and migrating shorebirds in southcentral Saskatchewan. Wilson Bull. 100: 554-566.

Connors, P.G., Myers, J.P. \& Pitelka, F.A. 1979. Seasonal habitat use by arctic Alaskan shorebirds. Stud. Avian Biol. 2: 101-111.

Connors, P.G., Myers, J.P., Connors, C.S.W. \& Pitelka, F.A. 1981. Interhabitat movements by Sanderlings in relation to foraging profitability and the tidal cycle. Auk 98: 49-64.

Cowardin, L.M., Carter, V., Golet, F.C. \& LaRoe, E.T. 1979. Classification of Wetlands and Deepwater Habitats of the United States. Washington, DC:U.S. Fish and Wildlife Service.

Dahl, T.E. 1990. Wetlands: Losses in the United States 1780's to 1980 's. Washington, DC: U.S. Fish and Wildlife Service.

De Solla, S.R., Bonduriansky, R.B. \& Brooks, R.J. 1999. Eliminating autocorrelation reduces biological relevance of home range estimates. J. Anim. Ecol. 68: 221-234.

Dias, M.P., Granadeiro, J.P., Lecoq, M., Santos, C.D. \& Palmeirim, J.M. 2006. Distance to high-tide roosts constrains the use of foraging areas by dunlins: implications for the management of estuarine wetlands. Biol. Conserv. 131: $446-452$.

Dick, W.J.A. \& Pienkowski, M.W. 1979. Autumn and early winter weights of waders in northwest Africa. Ornis Scand. 10:117-123.

Drake, K.R., Thompson, J.E. \& Drake, K.L. 2001. Movements, habitat use, and survival of nonbreeding Piping Plovers. Condor 103: 259-267.

Drake, K.R., Drake, K.L., Page, G.W., Sanzenbacher, P.M., Thompson, J.E. \& Haig, S.M. 2003. Capture of breeding and non-breeding shorebirds with leg-hold noose mats. J. Field Ornithol. 74: 401-405.

Evans, P.R. 1976. Energy balance and optimal foraging strategies in shorebirds: some implications for their distributions and movements in the non-breeding season. Ardea 64:117-139.

Evans Ogden, L.J., Hobson, K.A., Lank, D.B. \& Bittman, S. 2006. Stable isotope analysis reveals that agricultural habitat provides an important dietary component for nonbreeding Dunlin. Avian Conserv. Ecol. 1: 3 (http://www.ace-eco.org/ vol1/iss1/art3/).

Frayer, W.E., Monahan, T.J., Bowden, D.C. \& Graybill, F.A. 1983. Status and Trends of Wetlands and Deep Water Habitats in the Conterminous United States, 1950's to 1970's. Fort Collins, CO: Colorado State University.

Fredrickson, L.H. \& Reid, F.A. 1986. Wetland and riparian habitats: a nongame management overview. In Hale, J.B., Best, R.L. \& Clawson, R.L. (eds) Management of Nongame Wildlife in the Midwest: A Developing Art: 59-96. Grand Rapids, MI: The Wildlife Society.

van Gils, J.A., Dekinga, A., Spaans, B., Vahl, W.K. \& Piersma, T. 2005. Digestive bottleneck affects foraging decisions in red knots (Calidris canutus). II. Patch choice and length of working day. J. Anim. Ecol. 74: 120-130.

van Gils, J.A., Edelaar, P., Escudero, G. \& Piersma, T. 2004. Carrying capacity models should not use fixed prey density thresholds: a plea for using more tools of behavioural ecology. Oikos 104: 197-204.

van Gils, J.A., Spaans, B., Dekinga, A. \& Piersma, T. 2006. Foraging in a tidally structured environment by Red Knots (Calidris canutus): ideal, but not free. Ecology 87: 1189-1202.

Hooge, P.N. \& Eichenlaub, B. 1997. Animal Movement Extension to ArcView, Version 2.04. Anchorage, AK: Alaska Biological Science Center, USGS. 
Hulse, D., Gregory, S. \& Baker, J. 2002. Willamette River Basin Planning Atlas: Trajectories of Environmental and Ecological Change. Corvallis, OR: Oregon State University Press.

Jackson, P.L. \& Kimerling, A.J. 1993. Atlas of the Pacific Northwest. Corvallis, OR: Oregon State University Press.

Kushlan, J.A. 1986. Responses of wading birds to seasonally fluctuating water levels: strategies and their limits. Colon. Waterbirds 9: 155-162.

Lovvorn, J.R. \& Kirkpatrick, C.M. 1982. Field use by staging eastern Greater Sandhill Cranes. J. Wildl. Manage. 46: 99-108.

Luis, A., Goss-Custard, J.D. \& Moreira, M.H. 2002. The feeding strategy of the dunlin (Calidris alpina L.) in artificial and nonartificial habitats at Ria de Aveiro, Portugal. Hydrobiologia 475-476: 335-343.

Lyons, J.E. \& Haig, S.M. 1995. Fat content and stopover ecology of spring migrant Semipalmated Sandpipers in South Carolina. Condor 97: 427-437.

Mazur, K.M., Frith, S.D. \& James, P.C. 1998. Barred Owl home range and habitat selection in the boreal forest of central Saskatchewan. Auk 115: 746-754.

Mitsch, W.J. 1994. Global Wetlands: Old World and New. New York: Elsevier Science B.V.

Myers, J.P. 1986. Structure of Sanderling (Calidris alba) populations: the magnitude of intra- and interyear dispersal during the nonbreeding season. Proc. Int. Orn. Congr. 19: 604-615.

Otis, D.L. \& White, G.C. 1999. Autocorrelation of location estimates and the analysis of radio-tracking data. J. Wildl. Manage. 63: 1039-1044.

Pienkowski, M.W., Lloyd, C.S. \& Minton, C.D.T. 1979. Seasonal and migrational weight changes in Dunlins. Bird Study 26: 134-138.

Pitelka, F.A. (ed) 1977. Shorebirds in Marine Environments. Studies in Avian Biology no. 2. Los Angeles: Cooper Ornithological Society.

Plissner, J.H., Haig, S.M. \& Oring, L.W. 2000. Postbreeding movements of American Avocets and implications for wetland connectivity in the western Great Basin. Auk 117: 290-298.

Reed, J.M., Warnock, N. \& Oring, L.W. 1997. Conservation and management of shorebirds in the western Great Basin of North America. International Wader Studies 9: 1-81.

Robinson, J.A. \& Warnock, S.E. 1997. The staging paradigm and wetland conservation in arid environments: shorebirds and wetlands of the North American Great Basin. International Wader Studies 9: 37-44.

Rosa, S., Encarnacao, A.L., Granadeiro, J. \& Palmeirim, J.M. 2006. High water roost selection by waders: maximizing feeding opportunities or avoiding predation? Ibis 148: 88-97.

Roshier, D.A., Robertson, A.I., Kingsford, R.T. \& Green, D.G. 2001. Continental-scale interactions with temporary resources may explain the paradox of large populations of desert waterbirds in Australia. Landscape Ecol. 16: 547-556.

Ruiz, G.M., Connors, P.G., Griffin, S.E. \& Pitelka, F.A. 1987. Structure of a wintering Dunlin population. Condor 91: 562-570.

Rundle, W.D. \& Fredrickson, L.H. 1981. Managing seasonally flooded impoundments for migrant rails and shorebirds. Wildlife Soc. B 9: 80-87.

Sanzenbacher, P.M. 2002. Spatial and temporal movement patterns of wintering Dunlin (Calidris alpina) and Killdeer
(Charadrius vociferus) in the Willamette Valley, Oregon. MS Thesis, Oregon State University.

Sanzenbacher, P.M. \& Haig, S.M. 2002a. Residency and movement patterns of wintering Dunlin in the Willamette Valley of Oregon. Condor 104: 271-280.

Sanzenbacher, P.M. \& Haig, S.M. 2002b. Regional fidelity and movement patterns of wintering Killdeer in an agricultural landscape. Waterbirds 25: 16-25.

Sanzenbacher, P.M., Haig, S.M. \& Oring, L.W. 2000. Application of a modified harness design for attachment of radio transmitters to shorebirds. Wader Study Group Bull. 91: 16-20.

SAS Institute Inc. 1999. The SAS System for Windows, Version 8.2. Carey, NC: SAS Institute Inc.

Seaman, D.E., Griffith, B. \& Powell, R.A. 1998. Kernelhr: a program for estimating animal home ranges. Wildlife Soc. $B$ 26: $95-100$

Shepherd, P.C.F. \& Lank, D.B. 2004. Marine and agricultural habitat preferences of dunlin wintering in British Columbia. J. Wildl. Manage. 68: 61-73.

Skagen, S.K. \& Knopf, F.L. 1993. Toward conservation of midcontinental shorebird migrations. Conserv. Biol. 7: 533-541.

Skagen, S.K. \& Knopf, F.L. 1994. Migrating shorebirds and habitat dynamics at a prairie wetland complex. Wilson Bull. 106: 91-105

Smart, J. \& Gill, J. 2003. Non-intertidal habitat use by shorebirds: a reflection of inadequate intertidal resources? Biol. Conserv. 111: 359-369.

Symonds, F.L., Langslow, D.R. \& Pienkowski, M.W. 1984. Movement of wintering shorebirds within the Firth of Forth: species differences in usage of an intertidal complex. Biol. Conserv. 28: 187-215.

Taft, O.W. \& Haig, S.M. 2003. Historical wetlands in Oregon's Willamette Valley: implications for restoration of winter waterbird habitat. Wetlands 23: 51-64.

Taft, O.W. \& Haig, S.M. 2005. The value of agricultural wetlands as invertebrate resources for wintering shorebirds. Agri. Ecosyst. Env. 110: 249-256.

Taft, O.W. \& Haig, S.M. 2006. Importance of wetland landscape structure to shorebirds wintering in an agricultural valley. Landscape Ecol. 21: 169-184.

Taft, O.W., Haig, S.M. \& Kiilsgaard, C. 2004. Use of radar remote sensing (RADARSAT) to map winter wetland habitat for shorebirds in an agricultural landscape. Environ. Manage. 33: $749-762$

Warnock, S.E. \& Takekawa, J.Y. 1995. Habitat preferences of wintering shorebirds in a temporally changing environment: Western Sandpipers in the San Francisco Bay Estuary. Auk 112: 920-930.

Warnock, S.E. \& Takekawa, J.Y. 1996. Wintering site fidelity and movement patterns of Western Sandpipers Calidris mauri in the San Francisco Bay estuary. Ibis 138: 160-167.

Warnock, N., Page, G.W. \& Stenzel, L.E. 1995. Non-migratory movements of Dunlins on their California wintering grounds. Wilson Bull. 107: 131-139.

White, G.C. \& Garrott, R.A. 1990. Analysis of Wildlife RadioTracking Data. San Diego: Academic Press Inc.

Received 24 March 2007; revision accepted 4 February 2008. 